\title{
CONVERSÃO IN VITRO DE RAÍZES E FOLHAS DE Miltonia flavescens Lindl. EM PROTOCORMOS E REGENERAÇÃO DE PLANTAS
}

\author{
In vitro conversion of Miltonia flavescens Lindl. roots and leaf tip cells in protocorm \\ like bodies and plant regeneration
}

\author{
Suzana Stefanello', Juliane Karsten², Taina Soraia Müller ${ }^{3}$, Ana Paula Tomczak ${ }^{4}$, \\ Lucimar Pereira Bonett ${ }^{5}$, Adilson Ricken Schuelter ${ }^{6}$
}

\begin{abstract}
RESUMO
Objetivou-se, no presente trabalho, avaliar o efeito do 2,4-D e do BAP na formação de protocormos a partir de regiões meristemáticas da raiz e segmentos foliares de Miltonia flavescens Lindl., bem como testar o efeito de concentrações de sacarose e níveis de $\mathrm{pH}$ no crescimento in vitro dos protocormos. Ápices radiculares e segmentos de folhas de plantas germinadas in vitro foram inoculados em meio de cultura MS/2 suplementado com 2,4-D e BAP onde permaneceram por 210 dias no escuro, sendo transferidos para a luz e inoculados em meio de cultura isento de reguladores, avaliando-se a porcentagem de explantes com protocormos e o número médio de protocormos regenerados por explante. A associação de $3 \mathrm{mg} \mathrm{L}^{-1} \mathrm{de}$ 2,4-D e 1 ou $3 \mathrm{mg} \mathrm{L}^{-1}$ de BAP proporcionou os melhores resultados quanto à formação de protocormos. Esses foram cultivados em meio de cultura MS/2 onde testou-se o efeito da sacarose $\left(0,15,30,45\right.$ e $\left.60 \mathrm{~g} \mathrm{~L}^{-1}\right)$ e do $\mathrm{pH}\left(5.0,5.8\right.$ e 6.6) sobre o seu crescimento. As concentrações de 15 e $30 \mathrm{~g} \mathrm{~L}^{-1}$ de sacarose independentes do $\mathrm{pH}$, mostraram-se mais eficientes para o cultivo in vitro da espécie proporcionando a formação de um maior número e comprimento de raízes, altura de parte aérea e peso da matéria fresca. $\mathrm{O}$ pH só apresentou-se significativo quando em combinação com $15 \mathrm{~g} \mathrm{~L}^{-1}$ de sacarose para as variáveis comprimento da maior raiz e peso da matéria fresca.
\end{abstract}

Termos para indexação: Orchidaceae, reguladores de crescimento, sacarose, pH, Miltonia flavescens.

\section{ABSTRACT}

The aim of the present work was to evaluate the effect of 2,4-D and BAP on the protocorm formation from meristematic areas of the root and leaf segments of Miltonia flavescens Lindl., as well as to test the effect of sucrose concentrations and $\mathrm{pH}$ levels on the in vitro growth of protocorms. Root apexes and leaf segments of in vitro-germinated plants were cultured on MS/2 culture medium supplemented with 2,4-D and BAP and kept in the dark for 210 days. Explants were then transferred to light and cultured on culture medium lacking growth regulators. Percentage of explants with protocorms and average number of protocorms regenerated per explant were evaluated. The combination of $3 \mathrm{mg} \mathrm{L}^{-1} 2,4-\mathrm{D}$ and 1 or $3 \mathrm{mg} \mathrm{L}^{-1}$ BAP provided the best results for protocorm formation. Protocorms were cultured on MS/2 culture medium to test the effect of sucrose $\left(0,15,30,45\right.$, and $\left.60 \mathrm{~g} \mathrm{~L}^{-1}\right)$ and $\mathrm{pH}(5.0$, 5.8, and 6.6) on their growth. The concentrations of 15 and $30 \mathrm{~g} \mathrm{~L}^{-1}$ sucrose, independently of the $\mathrm{pH}$, were more efficient for the in vitro culture of this species, promoting an increase in the number and length of the roots, plant height, and fresh weight. The $\mathrm{pH}$ was significant only in combination with $15 \mathrm{~g} \mathrm{~L}^{-1}$ sucrose for the variables length of the largest root and fresh weight.

Index terms: Orchidaceae, growth regulators, sucrose, $\mathrm{pH}$, Miltonia flavescens.

(Recebido em 26 de março de 2008 e aprovado em 11 de julho de 2008)

\section{INTRODUÇÃO}

A família Orchidaceae constitui uma das maiores famílias de plantas floríferas, com mais de 800 gêneros, 35000 espécies e um grande número de híbridos (SHEEHAN, 1983). A importância da família está no potencial ornamental de suas flores, muito apreciadas por colecionadores e comerciantes.
Infelizmente no Brasil, e em outras partes do mundo, o cultivo e o comércio de orquídeas nativas teve como prática o extrativismo, que aliado à destruição de seus habitats naturais devido ao avanço da agricultura, levou à extinção ou à quase extinção de muitas espécies, dentre elas Miltonia flavescens Lindl., uma orquídea epífita nativa do Brasil e do Paraguai (IMES, 1997).

\footnotetext{
${ }^{1}$ Bióloga, Doutoranda em Genética e Melhoramento, Professora - Departamento de Biologia/DB - Universidade Paranaense/UNIPAR - Avenida Parigot de Souza, 3636 - Jardim Prada - 85903-170 - Toledo, PR - sstefanello@unipar.br

${ }^{2}$ Bióloga, Mestranda em Fisiologia Vegetal - Departamento de Biologia Vegetal - Universidade Federal de Viçosa/UFV - Avenida P.H. Rolfs - 36570-000 Viçosa, MG - julika4@yahoo.com.br

${ }^{3}$ Bióloga, Mestranda em Recursos Genéticos Vegetais - Departamento de Fitotecnia/FIT - Universidade Federal de Santa Catarina/UFSC - Rodovia Admar Gonzaga, 1346 - Itacorubi - Cx. P. 476 - 88034-001 - Florianópolis, SC - yhataina@yahoo.com.br

${ }^{4}$ Graduanda em Ciências Biológicas - Departamento de Biologia/DB - Universidade Paranaense/UNIPAR - Avenida Parigot de Souza, 3636 - Jardim Prada - 85903-170 - Toledo, PR - paulinhatomczak@hotmail.com

${ }^{5}$ Engenheira Agrônoma, Doutora em Agronomia, Professora - Departamento de Biologia/DB - Universidade Paranaense/UNIPAR - Avenida Parigot de Souza, 3636 - Jardim Prada - 85903-170 - Toledo, PR - lucimar@unipar.br

${ }^{6}$ Engenheiro Agrônomo, Doutor em Genética e Melhoramento, Professor - Departamento de Biologia/DB - Universidade Paranaense/UNIPAR - Avenida Parigot de Souza, 3636 - Jardim Prada - 85903-170 - Toledo, PR - adilson_schuelter@yahoo.com.br
} 
Para reverter esse quadro faz-se necessária a utilização de técnicas que permitam produzir um grande número de plantas a fim de repovoar os ambientes naturais, em curto espaço de tempo, ou seja, com velocidade de crescimento superior à obtida utilizando métodos convencionais de propagação. Assim, a cultura de tecidos pode ser uma boa alternativa para atender a esse propósito (GRATTAPAGLIA \& MACHADO, 1998).

Estudos utilizando orquídeas demonstraram que partes da planta como os ápices radiculares e folhas jovens, quando em condições adequadas de meio de cultura, podem induzir à formação de calos e protocormos permitindo a produção em larga escala de plantas superiores (CHEN \& CHANG, 2002; KERBAUY, 1993).

O meio nutritivo a ser utilizado precisa fornecer todas as substâncias essenciais para o crescimento dos tecidos e desenvolvimento in vitro. Apesar da formulação salina de Knudson (1946) ser a mais empregada para o cultivo in vitro de orquídeas, bons resultados têm sido obtidos em meio de cultura MS (MURASHIGE \& SKOOG, 1962) por vários autores (CHEN et al., 1999; CHEN \& CHANG, 2002, 2006; FARIA et al., 2004). Porém, torna-se necessário determinar as condições ótimas requeridas de nutrientes, $\mathrm{pH}$ do meio de cultura, reguladores e carboidratos para cada variedade (ARAÚJO et al., 2005).

Substâncias reguladoras de crescimento como as auxinas e as citocininas, geralmente são adicionadas ao meio de cultura para auxiliarem no desenvolvimento in vitro, influenciando a divisão e o alongamento celular (GRATAPAGLIA \& MACHADO, 1998).

Dentre os componentes do meio de cultura também estão os carboidratos, que fornecem energia metabólica e esqueletos carbônicos para a biossíntese de aminoácidos e proteínas, polissacarídeos estruturais e compostos orgânicos necessários para o crescimento das células. A sacarose é o carboidrato mais utilizado sendo que a sua concentração é um fator importante para se ter um ótimo crescimento dos explantes (SANTOS, 2003).

$\mathrm{O}$ efeito do $\mathrm{pH}$ dos meios nutritivos in vitro tem merecido atenção especial dos pesquisadores por sua atuação direta sobre a disponibilidade de nutrientes nele contidos (LEIFERT et al., 1992). As orquídeas geralmente se desenvolvem melhor em meio levemente mais ácido (ARDITTI, 1977).

Os estudos visando a obtenção de um protocolo regenerativo para $M$. flavescens são escassos. Há relatos da regeneração de plantas de Miltonia sp a partir de pseudobulbos (MOREL, 1964) e por meio da cultura de meristemas (MOREL \& CHAMPAGNAT, 1969, citados por MOREL, 1974).
Assim, objetivou-se avaliar o efeito de diferentes concentrações de 2,4-D e BAP na formação de protocormos, a partir de regiões meristemáticas da raiz e segmentos foliares de $M$. flavescens, bem como testar o efeito de concentrações de sacarose e níveis de $\mathrm{pH}$ no desenvolvimento in vitro dos protocormos.

\section{MATERIALE MÉTODOS}

\section{Material vegetal e condições de cultivo}

Os experimentos foram conduzidos no Laboratório de Biotecnologia e de Cultura de Tecidos Vegetais da Universidade Paranaense, Campus Toledo, Toledo, PR.

Sementes de $M$. flavescens retiradas de cápsulas imaturas, após passarem pelo processo de assepsia, foram inoculadas em frascos de vidro (capacidade 250 $\mathrm{mL}$ ), contendo $50 \mathrm{~mL}$ de meio de cultura basal MS com metade da concentração de sais (MS/2) suplementado com sacarose $\left(30 \mathrm{~g} \mathrm{~L}^{-1}\right)$, vitaminas do MS e ágar $\left(6.5 \mathrm{~g} \mathrm{~L}^{-}\right.$ $\left.{ }^{1}\right)$. As culturas foram mantidas em sala de crescimento a $25 \pm 2^{\circ} \mathrm{C}$, com fotoperíodo de 16 horas, sob irradiância de $40 \mathrm{mmol} \mathrm{m}^{-2} \mathrm{~s}^{-1}$ fornecida por lâmpadas fluorescentes brancas. Para a avaliação do efeito dos reguladores de crescimento na formação de protocormos, as culturas foram inoculadas em tubos de ensaio (22 x $150 \mathrm{~mm}$ ) contendo $10 \mathrm{~mL}$ de meio de cultura e incubadas no escuro. Para a avaliação do efeito da sacarose e do pH no crescimento dos protocormos, as culturas foram transferidas para frascos contendo $50 \mathrm{~mL}$ de meio de cultura, na presença de luz.

\section{Efeito de reguladores de crescimento na formação de protocormos}

Ápices foliares e radiculares $(0,5 \mathrm{~cm})$ provenientes de plantas germinadas in vitro e com aproximadamente 1 ano e seis meses de cultivo foram inoculados em meio de cultura basal MS/2 suplementado com diferentes combinações de 2,4-D - ácido diclorofenoxiacético (0, 3 e $\left.30 \mathrm{mg} \mathrm{L}^{-1}\right)$ e BAP - benzilaminopurina $\left(0,1\right.$ e $\left.3 \mathrm{mg} \mathrm{L}^{-1}\right)$. $\mathrm{O}$ delineamento experimental foi o inteiramente casualizado com dez repetições. Cada unidade experimental foi constituída de um tubo de ensaio com três explantes.

A avaliação de modificações morfogenéticas foi realizada a cada 30 dias até os 210 dias de cultivo. Após esse período o material foi exposto à luminosidade, submetido ao fotoperíodo de 16 horas e irradiância de $40 \mathrm{mmol} \mathrm{m} \mathrm{m}^{-2} \mathrm{~s}^{-1}$, permanecendo nessa condição por mais 30 dias. Os materiais vegetais que apresentaram respostas foram transferidos para novos 
tubos de ensaio contendo meio de cultura basal isento de reguladores de crescimento, onde permaneceram mais 120 dias, sendo subcultivados a cada 30 dias. Após esse período, avaliou-se a porcentagem de explantes radiculares e foliares que regeneraram protocormos e o número de protocormos formados por explante.

\section{Efeito da sacarose e do $\mathrm{pH}$ no crescimento in vitro de protocormos}

Protocormos com aproximadamente $0.3 \mathrm{~cm}$ e 0.001 $\mathrm{g}$, obtidos a partir de segmentos foliares e ápices radiculares cultivados em meio de cultura basal suplementado com 2,4-D (3 mg L $\left.\mathrm{m}^{-1}\right)$ e BAP ( $\left.1 \mathrm{mg} \mathrm{L}^{-1}\right)$, foram utilizados como explantes. Os mesmos foram inoculados em frascos contendo meio de cultura basal suplementado com diferentes concentrações de sacarose $(0,15,30,45$ e $60 \mathrm{~g}$ $\left.\mathrm{L}^{-1}\right)$ e $\mathrm{pH}$ (5.0, 5.8 e 6.6) ajustado utilizando hidróxido de sódio $(\mathrm{NaOH})$ ou ácido clorídrico $(\mathrm{HCl})$ a $1 \mathrm{~N}$, antes da adição do ágar.

O delineamento experimental utilizado foi inteiramente casualizado com cinco repetições. A unidade experimental consistiu de um frasco com dez explantes.

As plantas permaneceram durante 180 dias em cultivo, com um subcultivo aos 90 dias. Foi efetuada a avaliação das variáveis: altura da parte aérea, número de raízes, comprimento da maior raiz, número de folhas e o peso da matéria fresca. Os dados obtidos foram submetidos à análise de variância utilizando o programa estatístico Sisvar (FERREIRA, 1999) e comparação de médias através do teste de Scott-Knott, a 5\% de significância.

\section{RESULTADOS E DISCUSSÃO}

\section{Efeito dos reguladores de crescimento na formação de protocormos}

Inicialmente, praticamente todos os explantes permaneceram verdes quando cultivados no escuro em meio de cultura basal MS/2 na presença ou ausência de 2,4-D e BAP. Durante os dois primeiros meses de cultivo não foi observada a formação de calos sobre os explantes de nenhum tratamento, apenas um pequeno intumescimento nos ápices radiculares.

As primeiras modificações nos ápices radiculares cultivados in vitro foram observadas por volta dos 90 dias de cultivo. Surgiram massas nodulares de coloração branco-amarelada na extremidade da secção de alguns explantes cultivados em meio basal suplementado com 2,4-D e BAP (Figura 1 a) e após 210 dias foi possível visualizar protocormos originados a partir dessas massas (Figura 1 b). De modo similar, Kerbauy (1993) obteve protocormos de Oncidium varicosum Lindl. a partir de segmentos apicais de raízes após 210 dias de cultivo, porém em meio de cultura suplementado com ANA (1 e $2 \mathrm{mg} \mathrm{L}^{-1}$ ) e BAP $\left(0.05 \mathrm{mg} \mathrm{L}^{-1}\right)$.

Nos ápices foliares, as respostas morfológicas visíveis também começaram a aparecer após 90 dias de cultivo in vitro. Na extremidade seccionada de explantes cultivados em meio de cultura basal, sem a suplementação com reguladores de crescimento, observou-se a formação direta de um protocormo (Figura $1 \mathrm{c}$ ), sem formar uma massa nodular e após 30 dias originou-se uma planta completa de orquídea (Figura $1 \mathrm{~d}$ ). Massas nodulares também se tornaram visíveis sobre os explantes após 90 dias de cultivo em meio de cultura basal suplementado com 2,4-D (3 mg L-1) e BAP (1 ou $3 \mathrm{mg} \mathrm{L}^{-1}$ ), sobre a região seccionada do explante.

A adição de $3 \mathrm{mg} \mathrm{L}^{-1}$ da auxina sintética 2,4-D teve um efeito marcante na formação de massas nodulares que, posteriormente, originaram protocormos. Sua combinação com BAP (1 ou $3 \mathrm{mg} \mathrm{L}^{-1}$ ) foi importante pois incrementou a indução de massas nodulares tanto a partir de segmentos foliares quanto de ápices radiculares (Tabela 1). O maior número de protocormos utilizando ápices radiculares (213) foi obtido com a combinação $3 \mathrm{mg} \mathrm{L}^{-1}$ de 2,4-D e $3 \mathrm{mg} \mathrm{L}^{-1}$ de BAP, enquanto a combinação $3 \mathrm{mg} \mathrm{L}^{-1}$ de 2,4-D e $1 \mathrm{mg} \mathrm{L}^{-1}$ de BAP permitiu a indução de um maior número de protocormos a partir de segmentos foliares (245), embora em ambos os casos, a proporção de explantes com protocormos tenha sido baixa, diminuindo a média de protocormos por explante (7.1 e 8.2, respectivamente).

Os resultados obtidos foram similares aos relatados por Chen et al. (1999) com Oncidium 'Gower Ramsey'. Segmentos foliares produziram aglomerados de massas nodulares quando cultivados em meio de cultura MS/2 suplementado com 2,4-D e TDZ. Essas massas produziram embriões, inicialmente pequenos e brancos, os quais germinaram e passaram por sucessivos estádios de desenvolvimento. Murthy \& Pyati (2001) obtiveram protocormos a partir de segmentos de folhas jovens de plantas crescidas in vitro de Aerides maculosa Lindl., em meio de cultura MS suplementado com $2 \mathrm{mg} . \mathrm{L}^{-1}$ de BAP. O subcultivo dos protocormos em meio de cultura MS sem reguladores permitiu a diferenciação dos mesmos em plantas. 

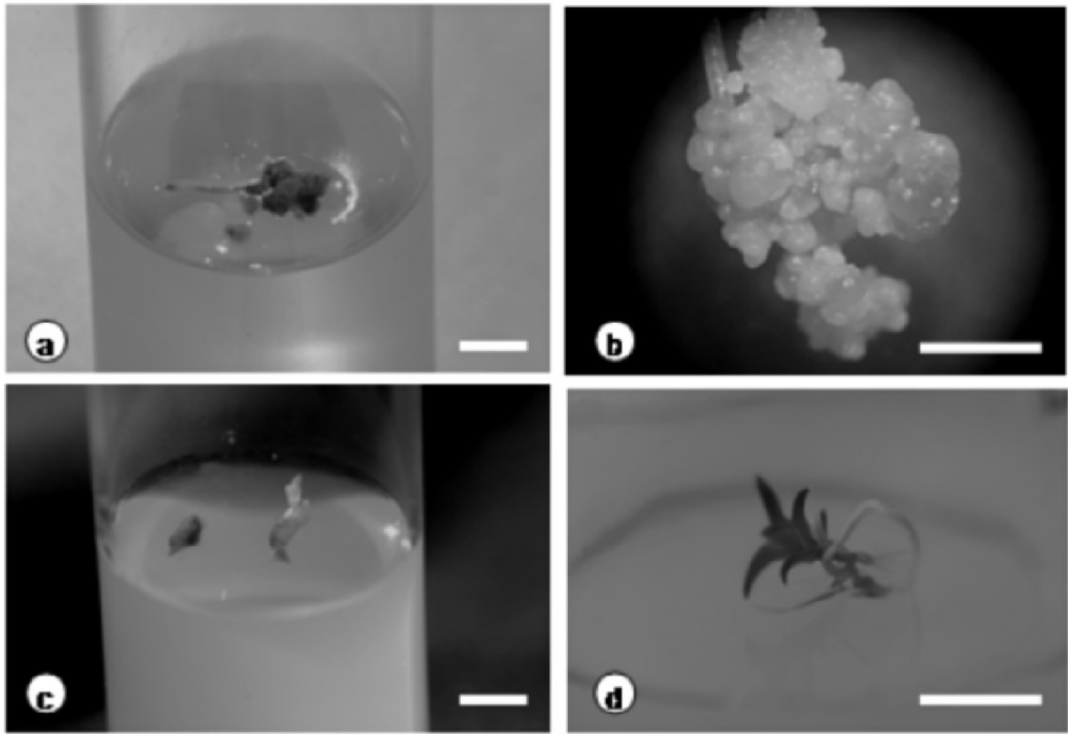

Figura 1 - Morfogênese in vitro de explantes radiculares e foliares de $M$. flavescens: a) ápice radicular cultivado com 2,4-D e BAP; b) formação de protocormos; c) segmento foliar regenerando orquídea; d) planta regenerada em meio de cultura sem regulador. Barra: $0,5 \mathrm{~cm}$.

Tabela 1 - Efeito do 2,4-D e do BAP na regeneração de protocormos a partir de ápices radiculares e segmentos foliares de Miltonia flavescens após 360 dias de cultivo in vitro (média de 30 explantes). Os valores máximos obtidos encontramse entre parênteses.

\begin{tabular}{cccccc}
\hline \multicolumn{2}{c}{ Concentração (mg.L $\left.{ }^{-1}\right)$} & \multicolumn{2}{c}{ Ápices radiculares } & \multicolumn{2}{c}{ Segmentos foliares } \\
\hline $2,4-\mathrm{D}$ & BAP & $\begin{array}{c}\text { \% explantes } \\
\text { com } \\
\text { protocormos }\end{array}$ & $\begin{array}{c}\mathrm{N}^{\circ} \text { médio de } \\
\text { protocormos } \\
\text { por explante }\end{array}$ & $\begin{array}{c}\text { com } \\
\text { protocormos }\end{array}$ & $\begin{array}{c}\mathrm{N}^{\circ} \text { médio de } \\
\text { protocormos } \\
\text { por explante }\end{array}$ \\
\hline 0 & 0 & 0 & 0 & 3.3 & $0.03(1)$ \\
0 & 1 & 0 & 0 & 0 & 0 \\
0 & 3 & 0 & 0 & 0 & 0 \\
3 & 0 & 6.6 & $1.2(36)$ & 0 & 0 \\
3 & 1 & 6.6 & $2.9(86)$ & 3.3 & $8.2(245)$ \\
3 & 3 & 3.3 & $7.1(213)$ & 3.3 & $2.7(81)$ \\
30 & 0 & 0 & 0 & 0 & 0 \\
30 & 1 & 0 & 0 & 0 & 0 \\
30 & 3 & 0 & 0 & 0 & 0 \\
\hline
\end{tabular}

Quando os protocormos foram expostos à luz, após 210 dias de cultivo in vitro no escuro, os mesmos tornaramse verdes e após a transferência para meio de cultura basal sem reguladores formaram raízes e folhas regenerando novas plantas de orquídeas. Protocormo é um termo usado para designar um estádio de desenvolvimento do embrião das orquídeas (KRAUS et al., 2006; MOREL, 1974). Segundo Morel (1974), as sementes de orquídeas contêm um embrião que é extremamente minúsculo, consistindo de poucas centenas de células. Seu desenvolvimento ocorre quando as sementes estão sob influência de fungos micorrízicos ou quando cultivadas em um meio nutritivo 
onde o protocormo é formado. Esses protocormos são primeiramente brancos, depois esverdeados, freqüentemente com longos rizóides em seus planos equatoriais e lentamente se desenvolvem em plantas.

\section{Efeito da sacarose e do $\mathbf{p H}$ no crescimento in vitro de protocormos}

Os dados relativos ao número de folhas coletados 180 dias após a inoculação dos protocormos, evidenciaram a não existência de efeito da concentração de sacarose e dos diferentes níveis de $\mathrm{pH}$, não apresentando diferenças significativas entre os tratamentos (Tabela 2).

Os resultados obtidos diferem dos encontrados por Ambrósio \& Melo (2004) ao estudarem a interação da sacarose e níveis de $\mathrm{pH}$ durante o cultivo in vitro de Nephrolepis biserrata (Sw.) Schott que observaram que as concentrações de 15 e $45 \mathrm{~g} \mathrm{~L}^{-1}$ de sacarose aumentaram o comprimento e o diâmetro das folhas e que, na ausência de sacarose, independente do nível de $\mathrm{pH}$ houve uma inibição da regeneração de brotos e folhas.

Os diferentes níveis de $\mathrm{pH}$ não influenciaram no número de raízes formadas, enquanto as concentrações de sacarose, que permitiram a formação de um maior número de raízes, foram 15, 30, 45 e $60 \mathrm{~g} \mathrm{~L}^{-1}$. A ausência do carboidrato fez com que as plantas apresentassem um baixo nível de enraizamento (Tabela 2). Collins \& Dixon (1992) verificaram que o enraizamento de brotações de Diuris longifolia $\mathrm{R}$. Br. foi favorecido pelo aumento da concentração de sacarose para $40 \mathrm{~g} \mathrm{~L}^{-1}$ ou pela adição de $0.05 \%$ de carvão ativado ao meio de cultura.

Faria et al. (2004) por outro lado, ao estudarem o crescimento e o enraizamento in vitro de plântulas de Dendrobium nobile Lindl. observaram que o acréscimo de sacarose no meio de cultura não influenciou o enraizamento in vitro das plantas.

Tabela 2 - Valores médios do número de folhas (NF), número de raiz (NR), comprimento da maior raiz (CR), altura da parte aérea (APA) e peso da matéria fresca (PMF) de plantas de M. flavescens após 180 dias de cultivo em meio de cultura MS/2 com diferentes concentrações de sacarose e níveis de $\mathrm{pH}$.

\begin{tabular}{|c|c|c|c|c|c|}
\hline & \multicolumn{5}{|c|}{ Concentrações $\left(\mathrm{g} \mathrm{L}^{-1}\right)$} \\
\hline & 0 & 15 & 30 & 45 & 60 \\
\hline & \multicolumn{5}{|c|}{$\mathrm{NF}$} \\
\hline pH 5.0 & $3.11 \mathrm{Aa}$ & $3.81 \mathrm{Aa}$ & $3.52 \mathrm{Aa}$ & $3.18 \mathrm{Aa}$ & $2.55 \mathrm{Aa}$ \\
\hline pH 5.8 & $2.79 \mathrm{Aa}$ & $3.62 \mathrm{Aa}$ & $3.54 \mathrm{Aa}$ & $3.19 \mathrm{Aa}$ & $2.77 \mathrm{Aa}$ \\
\hline $\mathrm{pH} 6.6$ & \multicolumn{4}{|c|}{ NR } & $2.56 \mathrm{Aa}$ \\
\hline pH 5.0 & $0.56 \mathrm{Aa}$ & $2.20 \mathrm{Ab}$ & $2.36 \mathrm{Ab}$ & $2.19 \mathrm{Ab}$ & $1.97 \mathrm{Ab}$ \\
\hline pH 5.8 & $0.51 \mathrm{Aa}$ & $2.12 \mathrm{Ab}$ & $2.32 \mathrm{Ab}$ & $2.38 \mathrm{Ab}$ & $2.06 \mathrm{Ab}$ \\
\hline pH 6.6 & \multicolumn{4}{|c|}{$\mathrm{CR}(\mathrm{cm})$} & $1.75 \mathrm{Ab}$ \\
\hline pH 5.0 & $0.27 \mathrm{Aa}$ & $1.09 \mathrm{Bc}$ & $0.98 \mathrm{Ac}$ & $0.68 \mathrm{Ab}$ & $0.69 \mathrm{Ab}$ \\
\hline pH 5.8 & $0.22 \mathrm{Aa}$ & $0.77 \mathrm{Ac}$ & $1.04 \mathrm{Ad}$ & $0.75 \mathrm{Ac}$ & $0.50 \mathrm{Ab}$ \\
\hline pH 6.6 & \multicolumn{5}{|c|}{$\mathrm{APA}(\mathrm{cm})$} \\
\hline pH 5.0 & $0.40 \mathrm{Aa}$ & $0.51 \mathrm{Ab}$ & $0.47 \mathrm{Ab}$ & $0.34 \mathrm{Aa}$ & $0.33 \mathrm{Aa}$ \\
\hline pH 5.8 & $0.34 \mathrm{Aa}$ & $0.49 \mathrm{Ab}$ & $0.50 \mathrm{Ab}$ & $0.41 \mathrm{Aa}$ & $0.34 \mathrm{Aa}$ \\
\hline \multicolumn{6}{|c|}{$\mathrm{PMF}(\mathrm{cm})$} \\
\hline $\mathrm{pH} 5.0$ & $0.0073 \mathrm{Aa}$ & $0.0134 \mathrm{Bb}$ & $0.0096 \mathrm{Ab}$ & $0.0051 \mathrm{Aa}$ & $0.0053 \mathrm{Aa}$ \\
\hline $\mathrm{pH} 5.8$ & $0.0055 \mathrm{Aa}$ & $0.0130 \mathrm{Bb}$ & $0.0137 \mathrm{Ab}$ & $0.0071 \mathrm{Aa}$ & $0.0056 \mathrm{Aa}$ \\
\hline pH 6.6 & $0.0081 \mathrm{Aa}$ & $0.0074 \mathrm{Aa}$ & $0.0108 \mathrm{Aa}$ & $0.0055 \mathrm{Aa}$ & $0.0049 \mathrm{Aa}$ \\
\hline
\end{tabular}

Médias seguidas da mesma letra maiúscula na vertical e minúscula na horizontal não diferem entre si pelo teste de Skott-Knott, a $5 \%$ de probabilidade. 
No presente trabalho não foi verificada a influência do $\mathrm{pH}$ no número de folhas e raízes. Estudos realizados por Silva et al. (2006) evidenciaram efeito significativo do $\mathrm{pH}$ na formação de folhas e raízes de híbridos de Cymbidium. O pH 5.3 mostrou ser superior ao $\mathrm{pH} 6.3$ no número total de folhas e raízes produzidas a partir de protocormos inoculados in vitro.

Para a variável comprimento da maior raiz, o pH 5.0 somente foi significativo na presença de $15 \mathrm{~g} \mathrm{~L}^{-1}$ de sacarose no meio de cultura $(1.09 \mathrm{~cm})$, sendo que os demais níveis de $\mathrm{pH}$ não mostraram influência. As melhores concentrações de sacarose para a variável em questão foram de 15, 30 e $45 \mathrm{~g} \mathrm{~L}^{-1}$. Segundo Grattapaglia \& Machado (1998), o tipo do sistema radicular, obtido no enraizamento in vitro também determina o sucesso do transplante, sendo as raízes mais curtas as mais adequadas, uma vez que apresentam-se em fase de crescimento ativo, facilitando a aclimatização da planta.

Não foi observado efeito do $\mathrm{pH}$ na altura da parte aérea, porém com a suplementação do meio de cultura com 15 e $30 \mathrm{~g} \mathrm{~L}^{-1}$ de sacarose foi observado maior desenvolvimento da parte aérea $(0.51$ e $0.50 \mathrm{~cm}$ respectivamente). Esses resultados diferem dos encontrados por Faria et al. (2004) com Dendrobium nobile onde $60 \mathrm{~g} \mathrm{~L}^{-1}$ de sacarose proporcionaram maior crescimento da parte aérea.

Os maiores valores do peso da matéria fresca $(0.0134$ e $0.013 \mathrm{~g}$, respectivamente) foram obtidos quando os protocormos foram cultivados em meio de cultura suplementado com $15 \mathrm{~g} \mathrm{~L}^{-1}$ de sacarose e $\mathrm{pH} 5.0$ e 5.8. Quando na ausência de sacarose ou com o acréscimo de 45 ou $60 \mathrm{~g} \mathrm{~L}^{-1}$, o pH não influenciou significativamente a variável.

Os resultados obtidos diferem dos encontrados por Rego-Oliveira et al. (2003) ao estudarem a influência da concentração de carboidrato no crescimento vegetativo e enraizamento in vitro de Oncidium varicosum, onde a concentração de $60 \mathrm{~g} \mathrm{~L}^{-1}$ de sacarose foi a melhor para todas as variáveis avaliadas.

As plantas propagadas in vitro necessitam de uma fonte de energia externa pois nessa fase são, praticamente, heterotróficas não encontrando as condições favoráveis para realizar a fotossíntese (CALDAS et al., 1998). Segundo Smeekens (2000), os carboidratos podem provocar alterações na expressão gênica similares às provocadas pelos hormônios. A percepção da sinalização dos açúcares por sensores protéicos provoca uma cascata de eventos a nível celular, alterando a expressão gênica e as atividades enzimáticas, tendo efeitos sobre a germinação, o crescimento vegetativo, o desenvolvimento reprodutivo e a formação das sementes.
A transferência das plantas cultivadas com $30 \mathrm{~g} \mathrm{~L}^{-1}$ de sacarose para a aclimatização em condições ex vitro, em bandejas contendo pó de coco como substrato, possibilitou a sobrevivência de $87,6 \%$ das plantas após 60 dias de cultivo.

\section{CONCLUSÕES}

A associação de $3 \mathrm{mg} \mathrm{L}^{-1}$ de 2,4-D e 1 e $3 \mathrm{mg} \mathrm{L}^{-1}$ de BAP proporciona os melhores resultados quanto à formação de protocormos a partir de ápices radiculares e segmentos foliares de $M$. flavescens. As concentrações de 15 e $30 \mathrm{~g} \mathrm{~L}^{-1}$ de sacarose independente do $\mathrm{pH}$, mostram-se mais adequadas para o cultivo in vitro da espécie, proporcionando a formação de um maior número e comprimento de raízes, altura de parte aérea e peso da matéria fresca. O pH só apresenta-se significativo quando em combinação com sacarose $15 \mathrm{~g} \mathrm{~L}^{-1}$ para as variáveis comprimento da maior raiz e peso da matéria fresca.

\section{REFERÊNCIAS BIBLIOGRÁFICAS}

AMBRÓSIO, S. T.; MELO, N. F. de. Interaction between sucrose and $\mathrm{pH}$ during in vitro culture of Nephrolepis biserrata (Sw.) Schott (Pteridophyta). Acta Botanica Brasílica, São Paulo, v. 18, n. 4, p. 809-813, 2004.

ARAUJO, A. G.; PASQUAL, M.; RODRIGUES, V. A.; SILVA, A. B.; SOARES, G. A. Concentração de $\mathrm{KNO}_{3}$ e $\mathrm{NH}_{4} \mathrm{NO}_{3}$ no crescimento in vitro de plântulas de orquídea. Plant Cell Culture \& Micropropagation, Lavras, v. 1, n. 1, p. 31-36, 2005.

ARDITTI, J. Clonal propagation of orchids by means of tissue culture: a manual. In: Orchid biology: reviews and perspectives. New York: Cornell University, 1977. v. 1, p. 203-293.

CALDAS, L. S.; HARIDASAN, P.; FERREIRA, M. E. Meios nutritivos. In: TORRES, A. C.; CALDAS, L. S.; BUSO, J. A. Cultura de tecidos e transformação genética de plantas. Brasília, DF: Embrapa-SPI/Embrapa-CNPH, 1998. v. 1, p. 87-132.

CHEN, J. T.; CHANG, W. C. Effects of tissue culture conditions and explant characteristics on direct somatic embryogenesis in Oncidium Gower Ramsey. Plant Cell, Tissue and Organ Culture, Dordrecht, v. 69, p. 41-44, 2002. 
CHEN, J. T.; CHANG, W. C. Direct somatic embryogenesis and plant regeneration from leaf explants of Phaleanopsis amabilis. Biologia Plantarum, Czech Republic, v. 50, n. 2, p. 169-173, 2006.

CHEN, J. T.; CHANG, C.; CHANG, W. C. Direct somatic embryogenesis on leaf explants of Oncidium Gower Ramsey and subsequent plant regeneration. Plant Cell Reports, New York, v. 19, p. 143-149, 1999.

COLLINS, M. T.; DIXON, K. W. Micropropagation of an Australian terrestrial orchid Diuris longifolia R. Br. Australian Journal of Experimental Agriculture, Collingwood, v. 32, n. 1, p. 131-135, 1992.

FARIA, R. T.; RODRIGUES, F. N.; OLIVEIRA, L. V. R.; MÜLLER, C. In vitro Dendrobium nobile plant growth and rooting in different sucrose concentrations. Horticultura Brasileira, Brasília, v. 22, n. 4, p. 780-783, 2004.

FERREIRA, D. F. Programa Estatístico SISVAR. Lavras: UFLA, 1999. Software.

GRATTAPAGLIA, D.; MACHADO, M. A. Micropropagação. In: TORRES, A. C.; CALDAS, L. S.; BUSO, J. A. Cultura de tecidos e transformação genética de plantas. Brasília, DF: Embrapa-SPI/Embrapa-CNPH, 1998. v. 1, p. $87-132$.

IMES, R. Orchids: the illutrated identifier to over 100 cultivated varieties. London: Apple, 1997. 80 p.

KERBAUY, G. B. Indução in vitro de protocormóides em raízes de Oncidium varicosum: efeitos de fontes nitrogenadas, auxinas e citocininas. Revista Brasileira de Botânica, São Paulo, v. 16, n. 1, p. 1-8, 1993.

KNUDSON, L. A. A new nutrient solution for the germination of orchid seed. American Orchid Society Bulletin, West Palm Beach, v. 14, p. 214-217, 1946.

KRAUS, J. E.; KERBAUY, G. B.; MONTEIRO, W. R. Desenvolvimento de protocormos de Catasetum pileatum Rchb.f. in vitro: aspectos estruturais e conceituais. Hoehnea, São Paulo, v. 33, p. 177-184, 2006.
LEIFERT, C.; PRYCE, S.; LUMSDEN, P. J.; WAITES, W. M. Effect of medium acidity on growth and rooting of different plant species growing in vitro. Plant Cell Tissue and Organ Culture, Netherlands, v. 30, n. 3, p. 171-179, 1992.

MOREL, G. M. Tissue culture: a new means of clonal propagation of orchids. American Orchid Society Bulletin, v. 33, p. 473-478, 1964.

MOREL, G. M. Clonal multiplication of orchids. In: WITHNER, C. L. (Ed.). The orchids. New York: J. Wiley and Sons, 1974. p. 169-222.

MURASHIGE, T.; SKOOG, E. A revised medium of rapid growth and biossays with tobacco tissue cultures. Physiologia Plantarum, Copenhagen, v. 15, p. 473-497, 1962.

MURTHY, H.; PYATI, A. Micropropagation of Aerides maculosum Lindl. (Orchidaceae). In Vitro Cellular and Development Biology Plant, Wallingford, v. 37, n. 2, p. 223226, 2001.

REGO-OLIVIERA, L. D.; FARIA, R. T.; FONSECA, I. C.; SACONATO, C. Influência da concentração de carboidrato no crescimento vegetativo e enraizamento in vitro de Oncidium varicosum Lindl. (Orchidaceae). Semina: Ciências Agrárias, Londrina, v. 24, n. 2, p. 265-272, 2003.

SANTOS, E. K. Totipotência celular e cultura de tecidos vegetais. In: FREITAS, L. B.; CERED, F. Genética e evolução vegetal. Rio Grande do Sul: UFRGS, 2003. p. 415-444.

SHEEHAN, T. J. Recent advances in botany propagation and physiology of orchids. Horticultural Reviews, New York, v. 5, p. 279-315, 1983.

SILVA, J. A. T. da; CHAN, M. T.; CHAI, M. T.; TANAKA, M. Priming abiotic factors for optimal hybrid Cymbidium (Orchidaceae) PLB and callus induction, plantlet formation, and their subsequent cytogenetic stability analysis. Scientia Horticulturae, Amsterdam, v. 109, n. 4, p. 368378, 2006.

SMEEKENS, G. S. M. Sugar-induced signal transduction in plants. Annual Review Plant Physiology and Plant Molecular Biology, Dordrecht, v. 51, p. 49-81, 2000. 